\title{
The Impact of Small - Scale Irrigation on Income of Rural Farm Households: Evidence from Ahferom Woreda in Tigray, Ethiopia
}

\author{
Abraham Gebrehiwot Yihdego ${ }^{1}$, Addis Adera Gebru ${ }^{2}$, Mesfin Tilahun Gelaye ${ }^{3}$ \\ ${ }^{1}$ Department of Economics, Faculty of Business and Economics, Woldia University, Woldia, Ethiopia \\ ${ }^{2}$ Department of Nursing, Faculty of Health Sciences, Woldia University, Woldia, Ethiopia \\ ${ }^{3}$ Department of Economics, College of Economics and Business, Mekelle University, Mekelle, Ethiopia \\ Email address: \\ addisaderagebru@gmail.com (A. A. Gebru),abigeb2@gmail.com (A. G. Yihdego)
}

\section{To cite this article:}

Abraham Gebrehiwot Yihdego, Addis Adera Gebru, Mesfin Tilahun Gelaye. The Impact of Small - Scale Irrigation on Income of Rural Farm Households: Evidence from Ahferom Woreda in Tigray, Ethiopia. International Journal of Business and Economics Research.

Vol. 4, No. 4, 2015, pp. 217-228. doi: 10.11648/j.ijber.20150404.14

\begin{abstract}
Background: Small scale irrigation is an important strategy in reducing risks associated with rainfall variability and increasing income of rural farm -households. Objective: To examine the impact of small-scale irrigation on income of rural farm households. It also presents the problems and challenges in use of small scale irrigation. Methods: A cross-sectional data obtained using a sample of 200 respondents selected through multi-stage random sampling techniques from three Tabiyas in Woreda Ahferom in central Tigray, Ethiopia in 2013/2014 cropping year. The data were analyzed using Heckman treatment effect two-step model. Result: The Probit estimation shows that Household head with social leadership, access to extension, and availability of irrigable land, number of oxen and family size have significant and positive effect whereas the family size square and distant to the nearest market restrains participation in small scale irrigation. The ordinary least square using household income as outcome variable reveals that Tropical Livestock Unit, participation in small scale irrigation and land size has significant positive effect on household income. Conclusion and recommendation: The study pointed out that loss of water, pests and diseases are the most common challenges in using small scale irrigation. Administration body and other concerned body should work the best on the quality, expansion and distribution of small scale irrigation by solving or at least mitigating the challenges face in using small scale irrigation.
\end{abstract}

Keywords: Small Scale Irrigation, Income, Heckman Two Step Treatment Effect Model, Woreda Ahferom

\section{Introduction}

Irrigation is one method of agricultural intensification and plays dominant role in increasing agricultural productivity. In the recent time it is obvious that, small scale irrigation is one of area of emphasis by policy makers and planners. Though Sub-Saharan Africa has a rich and varied water endowment, only four percent of its cropland is irrigated. Some 40 million hectares of its land are suitable for irrigation, but only 7.3 million hectares are actually irrigated. For millions of poor family in sub-Saharan Africa, access to water makes the difference between hunger and fully belly, between well nourished child and one stunted by malnutrition, and between productive livelihood and one mired in poverty. For many, the long dry season is a trying time of one meal a day. But the emergence and spread of affordable pumps and other technologies that enable farmers to irrigate their small plots has begun to boost harvests and family incomes in some world's deepest pockets of hunger, including parts of sub Saharan Africa(1). Drought resistance crops and crops requiring light irrigation are suggested for crop production during winter season(2). In many parts of the world including Ethiopia, the amount, frequency and distribution of rainfall, which is the principal source of water for crop production, is becoming more unpredictable and inadequate. Irrigation supports successful crop growing and stabilizes crop yields. In other words, irrigation is required in most of the places having uncertainty and uneven distribution of rainfall. This means in drought- prone areas of the country successful crop production is only possible with the support of irrigation (3).Scaling up the use of these small-holder irrigation systems should rise to the top of African development 
priorities. With targeted investments and policies to expand decentralized irrigation, the future for sub Saharan Africa's smallholder farmers could be bright. Without them hunger, poverty and humanitarian crises will persist (4).Irrigation increases agricultural productivity and farm income per hectare, according to previous studies (5). It insulates the national agricultural economic sector against weather related shocks and provides a more stable basis for economic growth and poverty reduction. However, the agricultural productivity is low due to use of low level of improved agricultural technologies, risks associated with weather conditions, diseases and pests, etc. (6). It supports the process of transforming traditional subsistence agriculture in to marketoriented production of high value crops (7). Agricultural production in Ethiopia is primarily rain fed, so it depends on erratic and often insufficient rainfall. As a result, there are frequent failures of agricultural production. Irrigation has the potential to stabilize agricultural production and mitigate the negative impacts of variable or insufficient rainfall. Irrigation development also can help offset some of the negative effects of rapid population growth (2.6\% per year in Ethiopia) ( 8). The modern history of Ethiopia shows that the country has failed to adequately feed itself. Food deficit and famine occurrences in the country is claimed to be as a result of the erratic nature of rainfall or drought. Ethiopia has faced three large-scale drought induced food shortage and famine in recent times (i.e. in 1972/73, 1983/84, 2002/03), which claimed thousands of lives. agrarian society of Ethiopia is not doing well in terms of agriculture and need transformation in increasing production, increase productivity and make sustainable agriculture that could cope with population growth, withstand climatic variability and limit agricultural expansion to marginal land. One of the ways to do so is through improved management of agricultural water and irrigation development, particularly small scale irrigation benefiting small holders(4). Irrigation in Ethiopia could represent a cornerstone of the agricultural development of the country, contributing up to 140 billion birr to the economy and potentially moving up to 6 million households into food security (9). Small-scale irrigation is a policy priority in Ethiopia for rural poverty alleviation and growth (10), only around $5 \%$ of Ethiopia's irrigable land is irrigated (11), and less than $5 \%$ of total renewable water resources are withdrawn annually (12), so there is considerable scope for expansion. Ethiopia has a potential of 5.3 million hectare arable land that can be cultivated through irrigation water. Considering the land and water resources potential the country has, massive volume of works have been undergoing now. With a view to ensuring food security both family-wise and nationally and to further increase agricultural outputs and earn foreign currently $(13,14,15)$. Before 1991, irrigation development in the country was almost non-existent. No policies and strategies were introduced by which it would be guided. Though there were few, their capacity level has been very minimal. There were no more than 61,000 hectare of land developed through irrigation during Derg regime. After 1991, with great emphasis made for irrigation by the government, significant changes have been observed. Policies and strategies were devised and national and foreign investors have been encouraged to engage in the irrigation development projects. By the end of 2009/10, national irrigation coverage stood on 2.4 percent. Up until the first year of the GTP, the area of land that had been developed through irrigation reached 127, 242.6 hectares. Planned growth of irrigation by the end of 2015 is 15.4 percent (13, $14,15)$. Although there is inadequate documented evidence regarding the history of irrigation practices in Tigray, some evidence dating back to $500 \mathrm{BC}$ indicates that irrigation was practiced in the ancient village of Yeha in Adwa and some other places. Descriptive data from the 50 communities surveyed indicate that 49 of the communities have access to two or three minor irrigation sources. Data also indicate that $90 \%$ of the micro-dams and $62 \%$ of the introduced river diversions were constructed after 1991. In Tigray, surface irrigation is the predominant form of irrigation; it includes spring development, river diversion, flood spreading, microdams and pond systems. The canal systems are mainly unlined and the density of tertiary canals on farmers, fields is often not high enough to ensure efficient water management. There are also limited ground water systems (16). Population of Woreda Ahferom is growing quickly, it is doubling almost every quarter of a century this has a negative effect in land holding and other natural resources, man to land ratio has increased significantly (17). Since, climate and technology are changed through time it needs updating / revising the policy of small scale irrigation in particular agriculture in general. This study will uses as the input to policy makers when they revise/update the policy.Threfore,the main aim of this study is to examine the impact of small scale irrigation on income of rural farm households.

\section{Methods and Materials}

\subsection{Study Area and Period}

Ahferom Woreda is found in the Central Zone of Region Tigray. Ahferom Woreda is located in the Northeast of the Central Zone with in a distance of $55 \mathrm{~km}$ from Axum, the capital of the Zone. A road that passes from Mekelle through Adigrat to Axum crosses the capital town of the Woreda. The Woreda ranges from $14006^{\prime} 30$ " to $14038^{\prime} 30^{\prime \prime}$ North in latitude and longitudinally from 380 56'30"to 390 18'0" East. It is bordering with Eritrea in the North, Gantafeshum and Gulomekeda Woredas in the East, Worei-leke Woreda in the South, Adawa and Merebleke Woredas in the West. There are two major rainy seasons in a year in the central zone in general. One rainy season starts in early March extending to early June while the second major rainy season extends from mid June to September (RDB, 2002). However, as the Woreda is one of the drought-prone areas, the mean annual rainfall of the Woreda for a series of years was found to be $579 \mathrm{~mm}$. According to RDB assessment, for instance, in the drought year of $2002 / 03$, there was no rain at all in the 14 first rainy season (March to June) and in the second season it 
started late in July 26 to withdraw early in September 6 in the zone as a whole. According to the above source, the Woreda has a total area of 133,500 hectares that accounts $25.40 \%$ arable land, $12.05 \%$ grazing land, $32.41 \%$ forest and woodland, $30.15 \%$ residence and other non-productive land. The soil in the Woreda is generally characterized as stony loams and sandy loams. The productivity of the soil is low due to low organic and nitrogen content. Ahferom Woreda is one of the densely populated areas of the country. The total population of the Woreda is estimated to be 131,168 in 1994 and 152,439 in 1999. Moreover, this is projected to reach 168,546 in 2003. According to TRFSD (2002), the rural population accounts $93 \%$ of the total population of the Woreda where the arable land is 33,979 hectares. Taking the projected population size in 2003 and the arable land, the population density is 4.96 persons/hectare of arable land. The Woreda is not different from the other parts of the country in having a high proportion of young age population and significant economic dependency ratio. According to CSA census 1994, the economically active age (15-64) accounts $51.1 \%$ of the total population while the balance $49.9 \%$ make up the 15 young (44.5\%) with an age of $<15$ and old age $(4.45 \%)$ greater than 64 of age group. Hence, the dependency ratio in the Woreda is $96 \%$. In respect of the number and sex of the head of the households in the Woreda, this source indicates that from a total number of 32,030 households $(69 \%)$ are male and $(31 \%)$ are female-headed households. The two major agricultural activities are crop production and animal husbandry. The major crops grown in the Woreda respectively according to their importance are 'teff', 'hanfets' (a mix of wheat and barley), gesho, wheat, sorghum, and millet. The study was conducted in this study area randomly selected farm households from July 2013 to June 2014 in Ahferom Woreda located in Northern Ethiopia, Tigray Region.

\section{Ahferom Woreda}

\section{Central Administrative Zone}

\section{Ahferom Woreda}

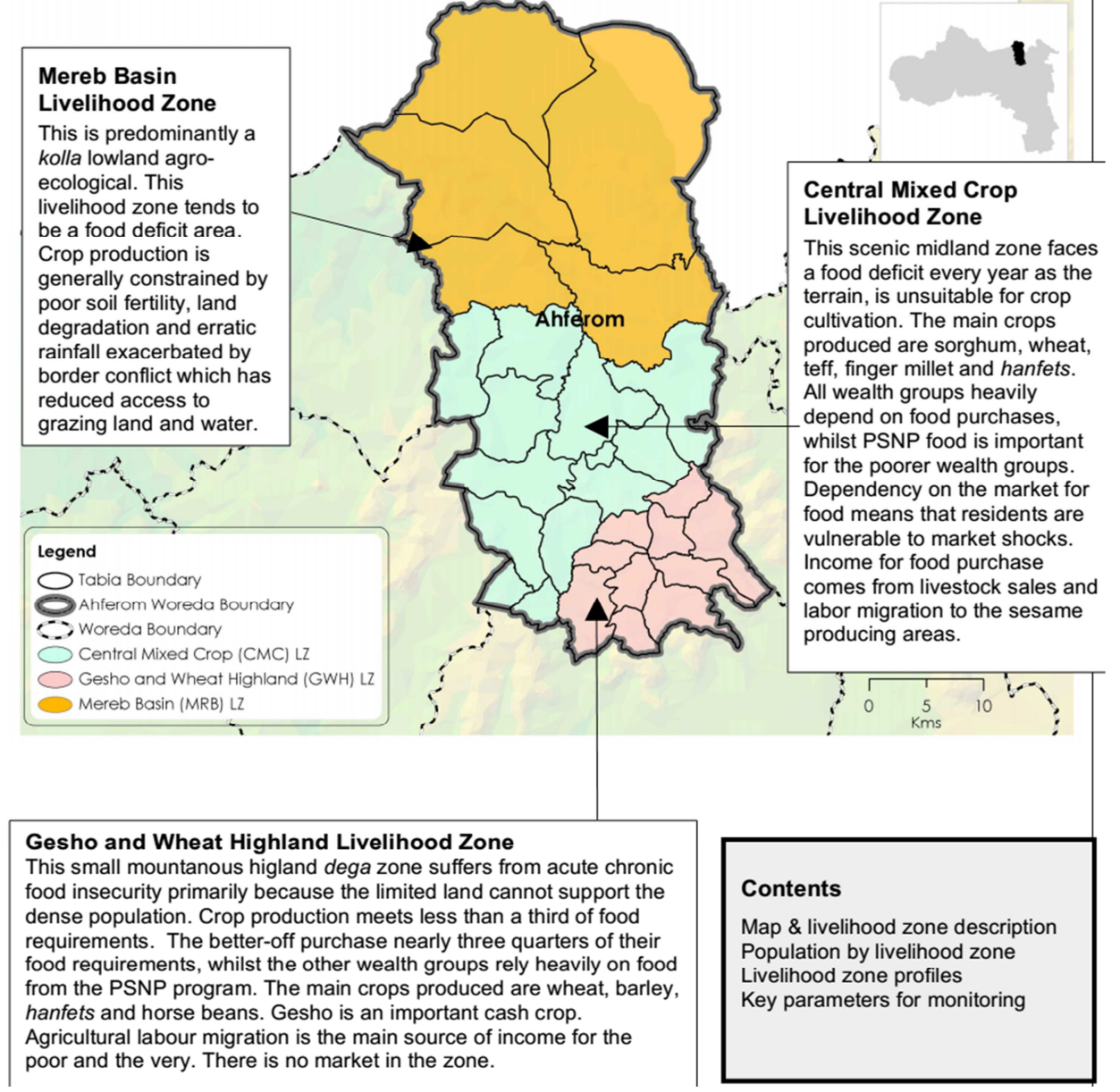

Source: Tigray Livelihood Zone Reports, 2007 


\subsection{Study Design}

A community based cross sectional study was employed.

\subsection{Study Population}

Sampled farm households were small-scale irrigation users and non-users in the selected study area. Irrigation users consists are households who own, rented/shared in/out or gifted in land for direct utilization, where as non-users is composed of households who neither owned irrigated land nor involved in irrigation farming.

\subsection{Sample Size}

A sample of 200 farm households is selected randomly; out of them 100 are irrigation users while 100 are non-users.

\subsection{Sampling Technique}

Two stage probability sampling technique was employed. In the first stage three irrigation centers is selected purposely because the availability of more irrigation users and representativeness of the population. Thus, the 'Tabias' or centers are selected which are Tabia Edaga-Arbi to represent the highland part of the Woreda, Tabiya Laelay Megariya Tsebri to represent the semi highland of the Woreda and Tabiya Sero to represent the low land part of the Woreda. In the second stage, the samples will be stratified in to users of irrigation and non users.

Therefore, the researcher is employed a probability type of sampling techniques which is proportional stratified sampling method.

\subsection{Econometric Model}

In practice, evaluating the impact of small-scale irrigation on income using linear regression analysis can lead to biased estimate if the underlying process which governs selection into small scale irrigation is not incorporated in the empirical framework. The reason for this is that the effect of the program may be over or underestimated if the program participants are more or less able (due to certain unobservable characteristics) to derive benefits compared to eligible non-participants (Zaman, 2001).Therefore, the Heckman two-stage estimation procedure, which assumes probit in the first step and ordinary least square (OLS) in the second step, is recommended to detect and avoid sample selection biases (Heckman, 1979). Inverse Mill's ratio, or lambda, was obtained from the probit equation and considered as one explanatory variable in the second equation. If its coefficient is statistically significant, selectivity biases are confirmed (Heckman, 1979; Greene, 2000). Then the model will specify as the following:

Participation/probit equation

$$
z_{i}^{*}=\sum_{k=1}^{k} \gamma_{k} w_{k i}+u_{i}
$$

Where, $Z_{i}^{*}=$ participation decision which has dichotomous realization on un observed $\mathrm{Z}_{\mathrm{i},}, \gamma_{k}=$ unknown parameters of the $\mathrm{k}$ variables $w_{k i}=$ variables determining probability of participation in irrigation utilization $u_{i}=$ disturbance term

Inverse miller's ratio/lambda is calculated

$$
\lambda\left(-\gamma w_{i}\right)=-\varphi\left(\gamma w_{i}\right) /{ }_{1-\phi}\left(\gamma w_{i}\right)
$$

Where, ${ }_{-} \varphi\left(\gamma w_{i}\right)=$ probability density function ${ }_{1} \phi\left(\gamma w_{i}\right)=$ cumulative normal distribution function

After we calculated the lambda it included in the outcome equation if it is significant, unless otherwise the model is inappropriate or there is no selection bias. In this case OLS is appropriate model.

Outcome/selection equation

$$
y_{i}=\sum_{s=1}^{s} \beta_{i} \chi_{s i}+\varepsilon_{i}
$$

$y_{i}$ is observed only if $\mathrm{Z}_{\mathrm{i}}^{*}>0$ and the disturbances $\varepsilon_{i}$ and $u_{i}$ follows a normal distribution with zero means and constant variances and covariance's which is $\sigma_{u \varepsilon}$. Where,

$y_{i}=$ the observed value of household income,

$\chi_{s i}=\mathrm{s}$ variables determining household income,

$\beta_{s}=$ vector of unknown parameters of the household income and $\varepsilon_{i}=$ error term

\subsection{Data Collection Procedure}

The study was used the two major types of data sources. There are primary sources of data and secondary sources of data. The primary type of data source is collected by structured questionnaire, personal interview, observation and focus group discussion. The researcher is selected structured questionnaire as the best data collection instrument, because it's convenient to mitigate non-response. The researcher also used interview, observation and focus group discussion as a positive technique of data collection to strengthen the data what the researcher gathered through the questionnaire and to get additional information. Thus the researcher employed survey research type, and the secondary data is gathered from irrigation Bureau of Woreda Ahferom, reference books and internets.

\subsection{Data Processing and Analysis}

The questionnaire and the data are checked for completeness and consistency. And the data was entered in to STATA software for investigation. To analyze data, the researcher is used both descriptive and econometric models. Descriptive statistical methods such as frequency, percentage, mean, and standard deviation is used. In addition to this, the researcher is used tables for data processing purpose. The researcher is used the above mentioned methods of data 
analysis and processing in order to easily understand by the users (readers) of the research. It is not only easily understandable but also easily applicable by the researcher. For categorical variables, a chi-square test is used to test for association. A t-test is used to examine the mean difference between irrigation users and non-users with respect to certain continuous variables.

\subsection{Operational Definition}

- Small-scale irrigation: is a type of irrigation which practices by rural farm households in small plot of land.

- Nonfarm income: any income gained out of their farm production.

- Irrigable land availability: a choice variable that is a proxy to access to water but the researcher uses instead of access to water to include households with near to water but no irrigable land.

- Woreda: is a district/area, which is one part of zone.

\subsection{Data Quality Control}

To ensure the quality of data, formerly the instruments including Models were pretested. The pretested was conducted in $5 \%$ of the participants at randomly selected study area away from the study area. Training was given for the data collectors and supervisors before the actual data collection. Every day after data collection, instruments were reviewed and checked for completeness, accuracy and clarity by the supervisors and principal investigator.

\subsection{Ethical Consideration}

Prior to the commencement of the study it was ethically cleared by the Research and Publication Office of Mekelle University and Ahferom Woreda Administration. In addition, the respondents were explained about the study and were request for their willingness to fill the questionnaires. The names of the respondents were not included in the questionnaire and in the results. All the filled tools were kept in strict confidentiality in a lockable cabinet.

\section{Results and Discussion}

As table 1 show, in the study area the average age of the user and non-user household heads is 45.85 and 44.57 years respectively. Consequently, age of the household head has not significant statistical difference between the user and non-user of small scale-irrigation. Thus, both the younger as well as the older household heads have statistically insignificant difference in irrigation participation (see table 1).But, education of the user and non-user is statistically significant at $(p<0.01)$ level of significance. The mean difference of education of the household heads is significant between users and non users of small-scale irrigation. Therefore, educated household heads are more likely to participate in irrigation in the study area. In other words, there is a statistical significant relationship between participation in small-scale irrigation and education of the household head. The average years of education of the user and non-user are 4.81 and 1.85 respectively. The mean of the user's education is 3 times larger than the mean of the non-users. Furthermore, as depicted in Table 1 family size of the user and non-user is significant at $(p<0.05)$ level of significance. So, small-scale irrigation and family size has a significant relationship. Households with large family size are motivated to participate more likely than households with small family size. Participation in irrigation requires more labor force as a result households with larger family size has cheaper labor that encourage them to practice in small scale irrigation. The average family size of the user and non-user on the study area is 5.07 and 4.15 respectively. Households with larger family size can perform different agricultural activities than their counterparts'/households with small family size. Likewise, as shown in Table 1 numbers of oxen owned have a statistically significant difference between users and non users of small scale irrigation. This indicates, households with more number of oxen are more likely to participate in small-scale irrigation because ox serves for plowing. On average the users and non-users of irrigation have 0.92 and 0.50 number of oxen's respectively. The users are 0.42 much greater than the nonusers in having of oxen on average. Dependency ratio of the user and non-user is 0.73 and 1.12 respectively. As the t-test value indicates that there is a significant relationship between the participation in irrigation and the dependency ratio of the household head. Households with higher amount of dependency ratio are less likely to participate in irrigation practice and vice-versa. Dependency ratio is significant at $(p<0.01)$ level of significance. Similarly as Table 1 shows that, distance to market is significant at $p<0.01$ level of significance. Distance to market is considered as a proximity variable for access to market. This result reveals that, as there is a significant relationship between the participation in irrigation and distance to market. Households with nearest to market are more likely to participate in irrigation but with too far apart are discouraged in selling of their agricultural products in the market. And with distant area households prefer to consume for themselves and sell it on their neighborhood with cheaper price. On average the mean distance of the user and non-user is $3.57 \mathrm{~km}$ and $8.47 \mathrm{~km}$ respectively. The non-users distance to market is $5 \mathrm{~km}$ exceeding than the users. Nonfarm income is statistically significant at $(p<0.01)$ level of significance. And this shows that non-farm income has a significant effect on the participation in irrigation. Household's engagement in non-farm income might not have higher probability of participation in irrigation in a sense the households with larger non-farm income might not necessarily participate in irrigation system. On average non-farm income earning of the users and non-users is 3233.48 Birr and 5165.14 birr respectively. The non-users non-farm income is 1931.66 Birr larger than the users nonfarm income earning. Since the large non-farm income motivates farm households to divert from agricultural activities participation to non-agricultural activities. Active 
labor force of the household head is significant at $(p<0.01)$ level of significance. Based on this result there is a significant difference in average active labor force availability between irrigation users and non users. Households composed with more active labor with in a family are more likely to participate in small-scale irrigation practices. On average 3.15 persons of the users are active labor forces whereas the non-users have 2.4 active labor force persons on average. In addition, land in hectare has a significant relationship with participation in irrigation. Land in hectare is significant at $(p<0.01)$ level of significance. Households with larger land in hectare have higher participation in small scale irrigation. Since they can be diversified in various agricultural activities rather than specializing in one. A farmer with larger and fertile land has higher participation in irrigation than their counterparts..
That is, farmers with large farm income are more likely to participate in irrigation practices than farmers with less farm income. The average farm income of the user and nonusers is 18602.16 Birr and 3975.459 Birr respectively. Higher farm income encourages farm households to participate and specialize in irrigation. Based on the surveyed result livestock ownership of a household have a significant relationship with access to irrigation at $(p<0.01)$ level of significance. The average livestock holding in tropical live stock unit of the user and non-user is 7.13 and 4.13 respectively. Though livestock holding is not a sufficient condition it is necessary to adopt small scale irrigation. However, households with more livestock holding are expected to participate in irrigation since it serves them as a wealth and can easily convert them in to cash when needed.

Table 1. Summary statistics of household characteristics of continuous variables.

\begin{tabular}{|c|c|c|c|c|c|}
\hline \multirow{2}{*}{ Variable } & \multicolumn{2}{|c|}{ User $=100$} & \multicolumn{2}{|c|}{ Non-user $=100$} & \multirow{2}{*}{ t-test } \\
\hline & Mean & Std.err & Mean & Std.err & \\
\hline Age of household head & 45.85 & 1.0196 & 44.57 & 1.5123 & -0.702 \\
\hline Education(years) & 4.81 & .2957 & 1.85 & .2634 & $-7.4756 * * *$ \\
\hline Family size & 5.07 & .2041 & 4.15 & .3144 & $-2.454 * *$ \\
\hline Number of Oxen & .92 & .0273 & .5 & .05025 & $-7.3462 * * *$ \\
\hline Dependency ratio & .73175 & .0841 & 1.1176 & .11832 & $2.6631 * * *$ \\
\hline Distance to market & 3.57 & .3604 & 8.47 & .4308 & $8.724 * * *$ \\
\hline Non-farm income & 3233.48 & 405.7506 & 5165.14 & 530.4652 & $2.8923 * * *$ \\
\hline Active labour family & 3.16 & .1698 & 2.4 & .16576 & $-3.203 * * *$ \\
\hline Land in hectare & 2.0295 & .094 & .8405 & .0444 & $-11.4321 * * *$ \\
\hline Total livestock unit & 7.13 & .33798 & 4.129 & .2904 & $-6.735 * * *$ \\
\hline
\end{tabular}

Source: own survey, 2014

Note: $* *$ significant at $5 \%, * * *$ significant at $1 \%$.

Gender of the farm household head shows a significant difference between the users and non users of small scale irrigation. The percentage of female headed households who are non-users of small scale irrigation is higher than the percentage of non user female headed households. While the percentage of user male headed households is higher than the percentage of non user male headed households. Indeed, from the participants of male headed households is $40 \%$ higher than female headed households and female headed households are $40 \%$ higher than males in the non participants of small scale irrigation. Householdhead social leadership has a significant relationship with participation in irrigation. Social position of a household encourages him highly to participate in irrigation schemes. Thus, $82.57 \%$ household heads with social leadership are irrigation participants and only $17.43 \%$ are non-users. This happens because of households with social leadership gets more information than counterparts. Access to credit has a significant relationship with access to irrigation (show table 2). Households with access to credit and without access to credit have significant difference in participation small scale irrigation. As result $83.19 \%$ households with access to credit are users while $16.81 \%$ of them are non-users of small scale irrigation. Access to credit refers to provision of credit for the farm households. Access to credit also has significant difference from participants and non-participants of small-scale irrigation. Thus, $83 \%$ of households with access to credit are participants in small scale irrigation, while only 6.9 percent of households without access to credit are participants of small scale irrigation. With regard to irrigable land availability, $67.65 \%$ of the users and 32.35 $\%$ of the non-users have irrigation water. And the p-value reveals that there is a significant relationship between access to irrigation and irrigation land availability at $1 \%$ probability level of significance. With regard to the result of the Table 2, 66.91\% of the users and $33.09 \%$ of the nonusers get access to extension service. From this result, extension service plays a great role in obtaining and getting of all the advices, training with all the agricultural activities performed by the farm households. As indicated, households with more extension service are more likely to participate than with less extension service provision of 
their counterparts.

Table 2. Summary statistics of household characteristics: using discrete variables.

\begin{tabular}{|c|c|c|c|c|}
\hline & & User $=100$ & $\begin{array}{l}\text { Non- } \\
\text { user=100 }\end{array}$ & \multirow[t]{2}{*}{ p-value } \\
\hline & & Percent & Percent & \\
\hline \multirow{2}{*}{ Gender } & Female & 18.60 & 81.40 & \multirow{2}{*}{$0.000 * * *$} \\
\hline & Male & 58.60 & 41.40 & \\
\hline \multirow{2}{*}{$\begin{array}{l}\text { Household } \\
\text { head social } \\
\text { leadership }\end{array}$} & No & 10.99 & 89.01 & \multirow[b]{2}{*}{$0.000 * * *$} \\
\hline & Yes & 82.57 & 17.43 & \\
\hline \multirow{2}{*}{$\begin{array}{l}\text { Access to } \\
\text { credit }\end{array}$} & No & 6.90 & 93.10 & \multirow{2}{*}{$0.000 * * *$} \\
\hline & Yes & 83.19 & 16.81 & \\
\hline \multirow{2}{*}{$\begin{array}{l}\text { Irrigable land } \\
\text { availability }\end{array}$} & No & 12.50 & 87.50 & \multirow{2}{*}{$0.000 * * *$} \\
\hline & Yes & 67.65 & 32.35 & \\
\hline \multirow{2}{*}{$\begin{array}{l}\text { Extension } \\
\text { service }\end{array}$} & No & 11.48 & 88.52 & \multirow{2}{*}{$0.000 * * *$} \\
\hline & Yes & 66.91 & 33.09 & \\
\hline
\end{tabular}

Source: Author's own computation, 2014

Small-scale irrigation has unquestionable potential to improve the incomes of poor rural households in developing countries like Ethiopia, but it is never free from problems. A field survey with focus group discussion and key informant interviews indicates that small-scale irrigation's great benefit is accompanied with multidimensional problems. The problem of small-scale irrigation starts from administration of the land and the water up to the most dangerous problems like loss of water, diseases and pests. The major problems encountered in use small-scale irrigation in the study area are problems related to lack of water, problem in the in the distribution of water, pests and diseases, thief and other animals eat the irrigation products, lack of supply inputs specially late supplying means no supplying in time.

Other factors like design issues, cultural factors, environmental problems are also other problems of in using small scale irrigation. According the survey data the three major problems of the irrigation users are depicted in table 3.The table 3 , indicates that diseases and pests are the main problem in the study area and 44.4 percent of the respondents designated as the first major problem in their irrigation land. This problem is more difficult because it hurts the products mostly at time of stars to give production. Thus, after farm households lose time, labor and material costs, diseases and pests may result only cost of the production without getting profit even normal profit. According to respondents' average estimation about the effect of the diseases and pests, they looses above quarter of their production. Therefore, until now it is the major headache for the users of agriculture in general, small scale irrigation in particular. Pests and diseases are more severe in the other seasons of the year when compare with summer. In summer, the water is more and results to decrease the diseases. And 44.4 respondents put this problem as second major problem in their irrigation practices. Only 10 percent of the respondents designated as third and above problem. See figure 2 it shows a sample picture of tomatoes affected by pests and disease in Tabiya Laelay Megaria Tsebri.

Table 3. Major problems in the use of small scale irrigation.

\begin{tabular}{|c|c|c|c|c|c|c|c|}
\hline \multirow{2}{*}{$\begin{array}{l}\text { Major problem in use of } \\
\text { small scale irrigation }\end{array}$} & \multicolumn{7}{|c|}{ Rank of the problems by the respondents } \\
\hline & First & $\%$ & Second & $\%$ & Third and above & $\%$ & Total \\
\hline Diseases and pests & 40 & 44.44 & 40 & 44.44 & 10 & 11.11 & 100 \\
\hline Loss of water & 36 & 40 & 40 & 44.44 & 14 & 15.56 & 100 \\
\hline Administration problem & 10 & 11.11 & 4 & 4.56 & 76 & 84.44 & 100 \\
\hline Other & 4 & 4.56 & 6 & 6.67 & 80 & 88.9 & 100 \\
\hline Total & 90 & 100 & 100 & 100 & 100 & 100 & \\
\hline
\end{tabular}

Source: Own survey, 2014

In general, the agricultural administrative bureau of the Woreda tries to mitigate the problem, by supplying pest sides and anti diseases. But it is not enough to solve the problem, because the supply has difficulty in distribution and late in time. Some of packages of pest sides and herb sides are not packaged in small unit. Thus, the farmer faces difficulty in grouping to get the large packaged imported pest sides and herb sides. In addition to this their cost is high.

Some causes of diseases are, intensively cultivated with the same crops for long periods of time. Onion and tomato are repeatedly grown crops. In addition to the loss of productivity and fertility, this cultivation strategy facilitates crop disease like root rot and cut warm. Imported inputs to control these problems, such as herbicides and pesticides, are costly for farmers to purchase. Therefore, diseases and pests can limit the economic benefits of small-scale irrigation activities in the study area.

The price of imported inputs such as fertilizer, chemical and fuel has increased over time, in part due to depreciation of the Ethiopian birr in world currency markets. One result is that the application of fertilizers on their farm plots is below the recommended levels. Chemicals like pesticides and herbicides are also costly to apply.

Loss of water is the second problem in small-scale irrigation systems in the study area. About 40 percent of the respondents designated loss of water as a first major problem in their small scale irrigated land.

The third major problem in the area is administration problem in distribution of water, inputs and training for the irrigators.

The other problem in the use of small scale irrigation in the study area is lack of spare parts for the pumps in the local 
market plus the expense of new ones causes difficulty for his irrigation activities. Therefore, it causes for water shortage in the study area in addition to evaporation and transpiration. Problems with irrigation water distribution also exist in the study area. This causes many conflicts between upstream and downstream irrigating households. The main cause of the problem is the amount of water and system of usage the available water. Mostly the system of usage is open for evaporation and wastage of water especially in the traditional river diversification small scale irrigation type. Thus, the upstream community always uses all amount of water through modern concrete canal or traditional river diversion. There are many households who use motor pump irrigation in the downstream but receive no water during parts of the year. This creates conflict between upstream and downstream water users.

Lack of spare parts for water pumps and shortage of fuel is an issue. The lack of imported spare parts for motor pumps and treadle pumps are main causes for reduced efficiency in small-scale irrigation in the study area. Since there are many traditional and modern wells in the study area, motor pump irrigation is used by many households. The main problems in motor pump irrigation are the frequent damage of the pump, lack of awareness of how to operate, cost of fuel and of the pump, and lack of credit. In the focus group discussion, Farmers are more interested with this motor pump because of its durability and ease to operate. Pedal pumps are the other small-scale irrigation technology in the study area. In the key Informant interview and focus group discussion the main problems with pedal pumps are lack of spare parts and nonfunctionality due to long service. The pedal pumps are also highly demanded by farmers but supply in the market is limited. The office of agriculture has substituted an Ethiopian-made pedal pump, but users complain about its weight (and therefore higher labor requirement to operate) and its low water pumping capacity. At present, most of these pedal pumps are non-functional because of lack of spare parts, but farmers still have high demand treadle pumps because of their simplicity to operate. Shortage of surface water is another problem. There are rivers that have water for only some of the dry months. Their seasonality is unpredictable, varies depending on the climatic conditions each year. This seasonality nature of rivers in the area causes water shortage especially at the flowering period of irrigated crops. The traditional river diversion and treadle pump irrigation users are more seriously affected by this type of water shortage. Traditional river diversion irrigation practiced on such simple rivers that can easily dry up. In the study area, treadle pump irrigation users use shallow well as their water source. However, these shallow wells dry out during dry months of the area January, February and March.

The last problem but not least for the small-scale users is passing their time and effort in food for work and other free public services. For example, PSNP is one of food for work program. The amount of work days and the value of the work are not matched, means for many work time they receive few wage in terms of cereals or birr. Even to implement the rule of the higher administrators, they go to the place of work and pass their time in work place without work. This is only for the purpose of report. In free service, they do the same activates all the year only for the purpose of report.

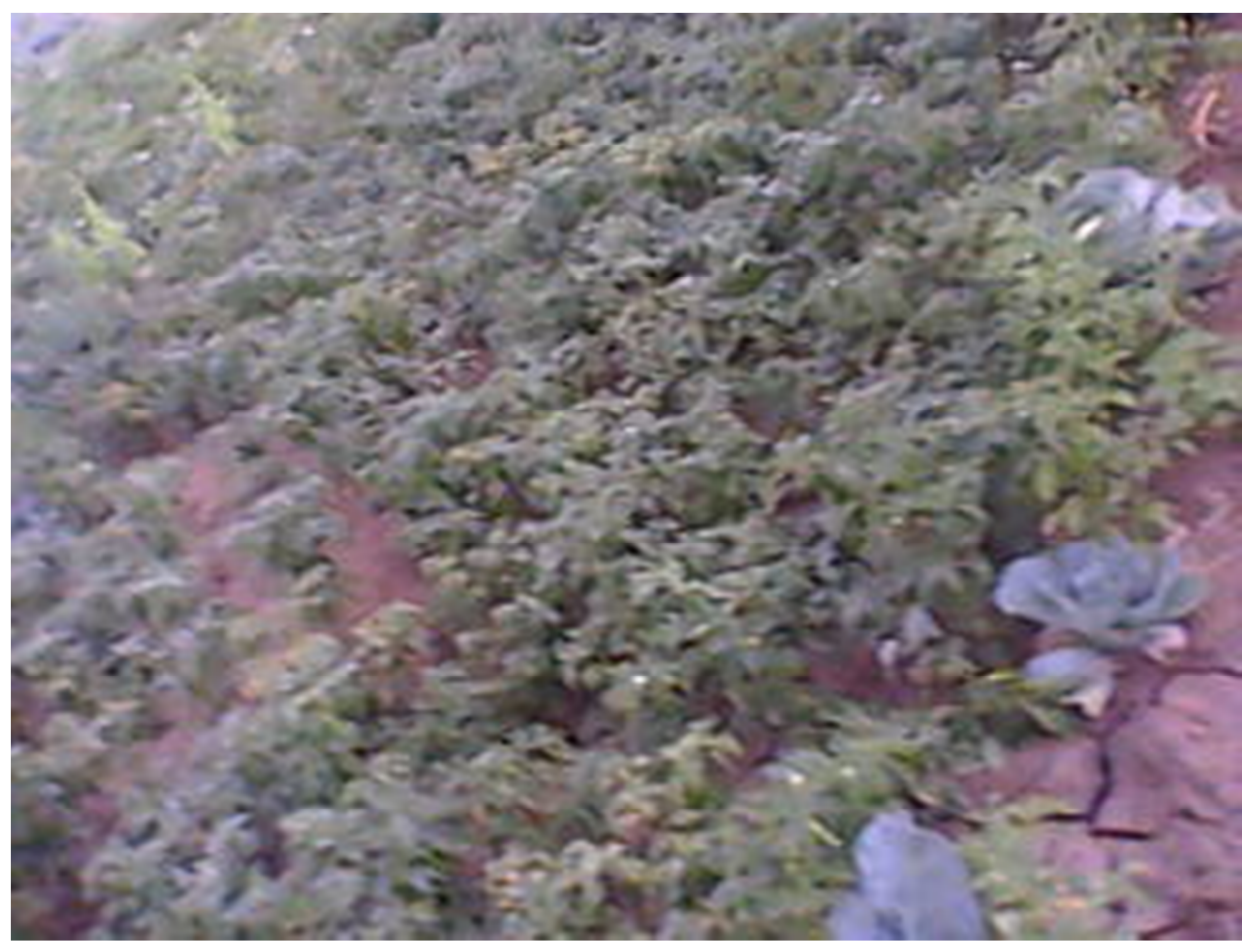

Source: survey picture, 2014. 


\section{Heckman treatment effect model result}

The probit treatment effect result indicates that household social participation, family size, number of oxen, access to extension service and availability of irrigable land are significant at $1 \%, 10 \%, 5 \%, 1 \%$, and $1 \%$ significance level respectively. And all affects positively to participation in irrigation. While, variables distant to market and family size square are negatively and siginificant at $5 \%$ level of significance affects to participation in irrigation. Household heads with irrigable land has larger probability of participate in irrigation by the marginal effect 55.7 percent than households' heads without irrigable land. Households with irrigable land are most probably to farm the land either themselves or by renting out or sharing out their land. But some of households are not participate totally in small scale irrigation even they have irrigable land. This due to many reasons like lack of awareness, lack of labor and lack of information about prices and related things. This variable also significance at $1 \%$ level of significance Household heads if they have social leadership participation has larger probability of participate in irrigation by the marginal effect 55.37 percent than households' heads without participation when others remain at their average. The main reasons are taking responsibility and getting information from local political administrations and sharing their knowledge among the social participants within and outside of their districts. In addition to this mostly participant get training. Other things hold constant, a one ox increase in the household the probability of Participation in small scale irrigation will be increase by the marginal effect of $19.98 \%$ Number of oxen is forgotten by most previous researches in irrigation, but it is one of the important factors in participation of small scale irrigation to rural farm households. It is significant at $1 \%$ level of significance, thus as the number of oxen increases by one unit participation in irrigation increases by the marginal effect of $19.98 \%$. Ox is one of the most important domestic animals use for farming purpose. Therefore, if numbers of oxen are high the household can farm himself its' own land and he can rent in and share in other lands for farming. This variable is missing in most previous researches. Other things hold constant, a one kilometer increases in distant to market will be decrease the probability of Participation in small scale irrigation by the marginal effect of $3.3 \%$. This is due to cost of production and access of information about the price of products in the market. If market is far transportation costs are high and probability of access to information about price of the products is low. As the result, probability of participation in irrigation decreases with farness of the nearest market. A one person increase in the family size square, the probability of Participation in small scale irrigation will be decrease by the marginal effect of $2.2 \%$. Therefore, as the family size increases more and more after some point leads to affect irrigation participation negatively, this is due to administration problems and increasing number of dependants.

Other things hold constant, a one person increases in the household family the probability of Participation in small scale irrigation will be increase by the marginal effect of $23.26 \%$. Because, as the family size increases, the labor of the household and the demand for resources increases as the result they began to work in different activities including participation in small scale irrigation to get more income to fill the additional demand. Household heads with access to extension service have more probability of participation in irrigation by the marginal effect 43.48 percent than without access to credit. Extension services are one of the important factors whether to participate or not in irrigation because the household's information about irrigation is more depend on extension. This is also supported by most previous researches like (18).

Table 4. Treatment probit/participation model.

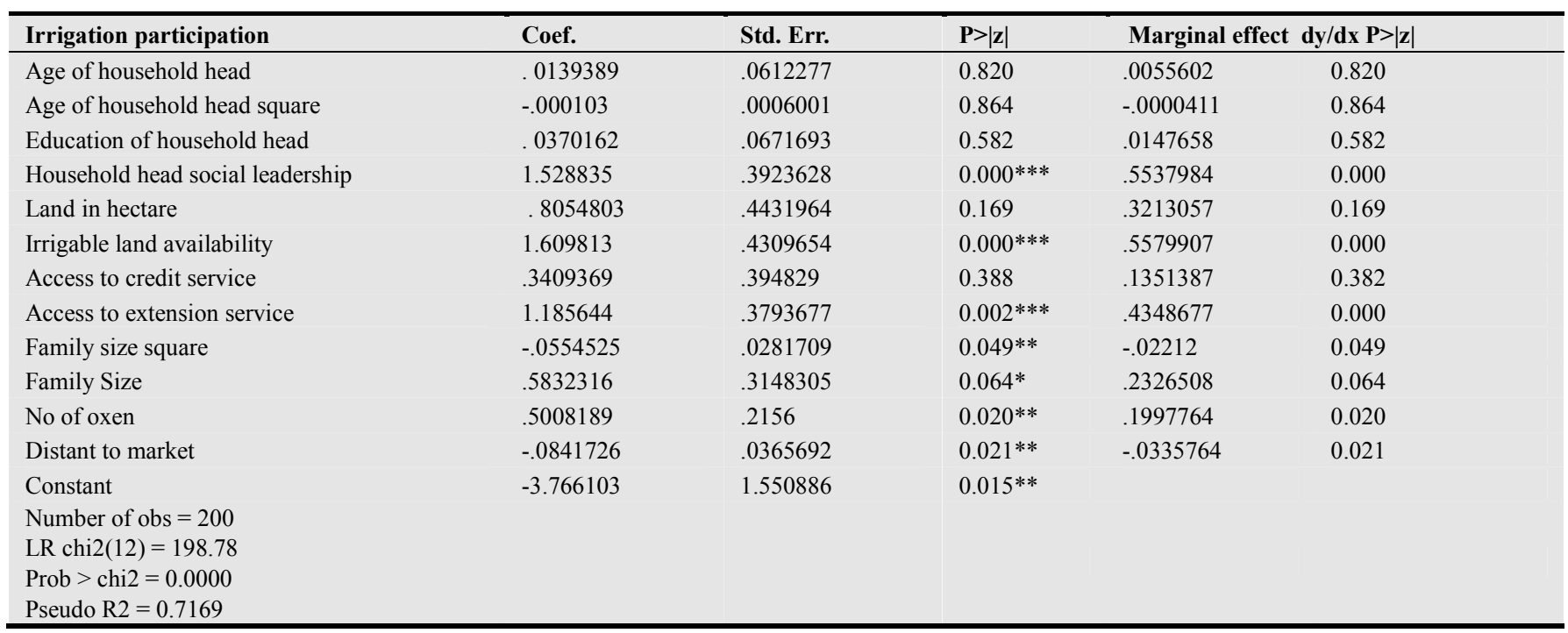

$* * *, * *$, and $*$ significant at $1 \%, 5 \%$, and $10 \%$ level of significance respectively.

Source: Survey data, 2014 
The hazard lambda is significant and this supports using of the model. In this outcome model other things remains constant, land in hectare is positive and significantly at $1 \%$ significance level affects the income of rural farm household. If the household land size increases by one hectare income of the family increases by 8788.82 birr. And also, as the tropical livestock unit increases by one unit, income of the household increases averagely by 771.51 birr, other things holding constant. This is due to importance of livestock and live stock results in rural areas in getting income. And this result is consistent with the theory and previous research results it is positive and significant at $1 \%$ significance level to affect income of farm households this also similar with the result of previous research (18-24). The impact of irrigation participation on income is positive and significant at 5\% level of significance. Other things holding constant, in average households with users/participation in small scale irrigation have greater income by 9423.37 birr when we compared with non users or non participants. This results also, similar with the researcher's hypothesis. The researcher's hypothesis is small scale irrigation has positive impact on income of rural farm households (show table 5)

Table 5. Treatment-effects model -- two-step estimates (the outcome model).

\begin{tabular}{|c|c|c|c|}
\hline Income & Coef. & Std. Err. & $\mathbf{P}>|\mathbf{z}|$ \\
\hline Age of household head & 228.5395 & 333.362 & 0.493 \\
\hline $\begin{array}{l}\text { Age of household head } \\
\text { square }\end{array}$ & -1.731246 & 3.310891 & 0.601 \\
\hline $\begin{array}{l}\text { Education of household } \\
\text { head }\end{array}$ & 214.8152 & 291.9012 & 0.462 \\
\hline Land in hectare & 8788.827 & 1591.884 & $0.000 * * *$ \\
\hline Access to credit service & 986.5116 & 2145.27 & 0.646 \\
\hline Tropical livestock unit & 771.5144 & 263.1038 & $0.003 * * *$ \\
\hline Family Size & -1520.145 & 1408.999 & 0.281 \\
\hline Family size square & 167.8259 & 118.3262 & 0.156 \\
\hline $\begin{array}{l}\text { Access to extension } \\
\text { service }\end{array}$ & -753.6968 & 1949.133 & 0.699 \\
\hline $\begin{array}{ll}\text { Irrigable } & \text { land } \\
\text { availability } & \end{array}$ & 1881.744 & 2123.308 & 0.375 \\
\hline Sex of house hold head & 904.5081 & 2052.782 & 0.659 \\
\hline Irrigation participation & 9423.371 & 3735.476 & $0.012 * *$ \\
\hline Constant & -8437.334 & 7684.074 & 0.272 \\
\hline Hazard lambda & -6297.249 & 2414.124 & 0.009 \\
\hline Rho & -0.63022 & & \\
\hline Sigma & 9992.0827 & & \\
\hline Lambda & -6297.2488 & 2414.124 & \\
\hline
\end{tabular}

$* * *, * *$, and $*$ significant at $1 \%, 5 \%$, and $10 \%$ level of significance respectively.

Source: Survey data, 2014

\section{Conclusion}

The descriptive statistics result showed that variables education of household family size, number of own oxen and active labor of the family, amount of own land and farm income significant at $1 \%$ significance level and positively affects participation in irrigation and dependency ratio, distance to market, and non farm income are negatively affects the decision to participation in small scale irrigation. Thus are continuous variables. Moreover, the study pointed out that loss of water due to different reasons, pests \& diseases and administration problems are the most common challenges in using small scale irrigation. In addition thieves and animals and other lack of inputs also challenges in using irrigation. The respondents said that pests and disease are headache for us because, they spoils out our all effort usually at eve or time of production. But it doesn't found attention by the government as much as other inputs of irrigation in particular and agriculture in general. From the binary variables sex of household, access to extension and access to credit and household head social participation have significant difference between irrigation users and non users at $1 \%$ significance level. The econometric model results from the Heckman two step treatment effect model is conclude that small scale irrigation has positive and significant impact on income of farm households. According to Heckman, probit estimation result shows that household head with social leadership, access to extension, family size, availability of irrigable land and number of oxen have significant and positive effect Whereas the family size square, and distant to the nearest market restrains participation in small scale irrigation. The ordinary least square using household income as outcome variable reveals that land size, TLU and irrigation participation have significant positive effect on household income. From the above result the researcher concludes that small scale irrigation is unquestionably boosts the income of rural farm households.

\section{Recommendation}

- Small- scale irrigation has very significant positive income of rural farm households, in spite of this it has many constraints and its coverage is limited. So the government and other concerned body should work in expansion and its technological development.

- Diseases and pests are common in the irrigation and according to the users of the irrigation pesticides and other anti diseases are very limited in supply and some of them are not favorable in their usage and even supplied late. Therefore, government and other concerned body should do the best on it, means if possible for the common diseases should supply protective anti pests before. And for the uncommon diseases by doing researches and other studies on that should supply as soon as possible.

- Not only diseases and pests are challenges in irrigation but also loss of water due to many reasons and administrative problems are common. Therefore, government and other concerned body should try to solve or at least to mitigate the challenges faces in small scale irrigation.

- The government or other concerned body should have to create awareness and providing credit service for 
buying oxen or giving oxen in credit for the households with no ox is important to boost irrigation and agriculture

- Government and other concerned body should do to boost in quality and quantity of credit and extension services.

- Adding to the quality, expansion in its quantity and distribution, solving or at least mitigating the problems it faces, creating awareness through training and extension and expansion of credit services are important factors to increase and improve in quality and amount of irrigation, and results to increase income.

- At last but not least, the government and other concerned body should encourage researches on agriculture in general and irrigation in particular.

\section{Authors' Contributions}

AGY have made substantial contributions to beginning and design, collection of data, analysis and interpretation of data and in drafting the manuscripts and correcting the comments given by the advisors.

MTG involved in revising the research paper and the manuscript critically for important intellectual context and approval of the final version to be published and participated in its description. They participated in the design of the study participated in its design and coordination.

AAG involved in revising the paper and the manuscript critically for the sake of intellectual context and approval of the final version to be published and participated in its design and coordination. In addition to this, they had great contribution in reviewing the manuscript English and Topography and helped to draft the manuscript.

\section{Acknowledgement}

We are thankful to all department technical staffs for their excellence technical support. We are grateful to all the participants for their cooperation and Mekelle University for financial support.

\section{References}

[1] IWMI (International Water Management Institute) (2012). Experiences and opportunities for promoting small-scale micro irrigation and rain water harvesting for food security in Ethiopia, Working paper 98. IWMI: Addis Ababa.

[2] Sarker, KK.,Alam,MdA.,Hasan,MK.,Mondol,MRH(2014). Evaluation and Future Options for Hillock Crop Production System in Lalmai Region of Bangladesh. Agriculture, Forestry and Fisheries.3(4):313-319. doi: 10.11648/j.aff.20140304.24

[3] MOA,(2010). Ministry of Agriculture and rural development; report of Agriculture., Ethiopia.

[4] IWMI (International Water Management Institute) (2011). Experiences and opportunities for promoting small-scale micro irrigation and rain water harvesting for food security in
Ethiopia, Working paper 98. IWMI: Addis Ababa. Sleshi Bekle (2011). Assessment of Small Scale Irrigation and Water Harvesting in Ethiopian Agricultural Development International Water Management Institute (IWMI).

[5] Nhundu, Kenneth (2013). Determinants of farmer participation in irrigation development post fast track land reform programme a case study of Mashonaland East Province Zimbabwe. International Journal of Development and Economic Sustainability Vol.1, No. 1, 2013.

[6] Alamerie,K., Ketema,M., Gelaw,F(2014). Risks in Vegetables Production from the Perspective of Smallholder Farmers: The Case of Kombolcha Woreda, Oromia Region, Ethiopia. Agriculture, Forestry and Fisheries. Special Issue: Agriculture Ecosystems and Environment. 3(6-1): 1-5. doi:10.11648 /j.aff. s.2014030601.11

[7] Nhundu, K, Gwata, C, Mushunje, A.2010. Impacts of Zimbabwe European Union micro-project programme ( $\mathrm{Zim} / \mathrm{Eu} \mathrm{MPP})$ in funding smallholder irrigation projects on food security and income levels: A case study of Mopane irrigation.

[8] Awulachew, S. B.; Merrey, D.; Kamara, A.; Koppen, B. V.; de Vries, F. P.; Boelee, E.; Makombe, G. (eds). 2005. Experiences and Opportunities for Promoting Smallscale/micro- irrigation and Rainwater Harvesting for Food Security in Ethiopia. Colombo, Sri Lanka: International Water Management Institute. 86p. (IWMI Working Paper 98).

[9] Bernard Chazovachii.(2012). The impact of small scale irrigation schemes on rural livelihoods: the case of panganai irrigation scheme bikita district Zimbabwe. Journal of sustainable development in Africa (volume 14, no.4, 2012) clarion university of Pennsylvania.

[10] CSA (Central Statistics Agency). 2007. Summery and statistical report of 2007 population and housing census of Ethiopia, Ethiopia.

[11] IWMI (International Water Management Institute) (2010). Experiences and opportunities for promoting small-scale micro irrigation and rain water harvesting for food security in Ethiopia, Working paper 98. IWMI: Addis Ababa.

[12] Graciana Peter(2011) the impact of small scale irrigation schemes on household food security in Swaziland, Journal of Sustainable Development in Africa (Volume 13, No.6,).

[13] MOFED (Ministry of Finance and Economic Development) 2006. Ethiopia: Building on Progress. A Plan for Accelerated and Sustained Development to End Poverty. (2005/062009/10). Volume I: Main Text. Ministry of Finance and Economic Development (MoFED). September, 2006.

[14] Marrit Van Den Berg \& Ruerd Ruben. (2006). Small-Scale irrigation and income distribution in Ethiopia, Wageningen University, The Netherlands Published online.

[15] Mujere, N. Chazovachii, B., Chifodya, G and Mushuku, A (2010) Evaluating Factors Influencing The Variation Of Irrigated Wheat Yields. A Case Study Of Chinyamatumwa Irrigation Scheme In Zimbabwe. Journal of Sustainable Development in Africa 2011, Vol 13, No.4.

[16] Zaman H.(2006), Assessing the poverty and vulnerability impact of micro credit access in Bangladesh, a Case Study of BRAC, Office of the Chief Economist and Senior Vice President, the World Bank. 
[17] Seoul A.(2013). Evaluating the effects of irrigation on poverty reduction and income distribution in the Nile Basin: A lesson from Banjo Worde of the Amhara Region (Ethiopia), Vol. 3(2): 105-113.

[18] Sisay Belay and Fekadu Beyene. (2013). Small-scale irrigation and household income linkage: Evidence from Deder district, Vol. 8( 34),Ethiopia.

[19] MOFED.(2010).The Federal Democratic Republic of Ethiopia, Growth and Transformation Plan (GTP) 2010/11-2014/15, Draft. 2010 September, Addis Ababa.

[20] Seleshi Bekele Awulachew and Douglas J. Merrey.(2013). Assessment of Small Scale Irrigation and Water Harvesting in Ethiopian Agricultural Development, International Water Management Institute (IWMI).
[21] Http://www.ilri.cgiar.org(18/12/2011/12).

[22] Hussein Kebede and Ermias Birru, (2011). Guideline irrigation agronomy on ministry of agriculture, natural resource sector, Addis Ababa, Ethiopia.

[23] Intizar Hussain.(2007). Direct and indirect benefits and potential dis-benefits of irrigation: evidence and lessons International Network on Participatory Irrigation Management (INPIM), Islamabad, Pakistan (Formerly Senior Economist, International Water Management Institute (IWMI), Colombo, Sri Lanka.

[24] SERA (Strengthening Emergency Response Abilities) Vulnerability Profile Ahferom Woreda, Central Zone, Tigray Region (2000). 